\title{
Blood Ghrelin, Adiponectin and Resistin Levels During Controlled Ovarian Stimulation in IVF Cycles
}

\author{
K. DAFOPOULOS ${ }^{1,3}$, C. I. MESSINI ${ }^{1}$, G. ANIFANDIS ${ }^{1}$, P. GEORGOULIAS ${ }^{2}$, \\ D. SOURLAS ${ }^{1}$, I. E. MESSINIS ${ }^{1}$
}

${ }^{1}$ Department of Obstetrics and Gynecology, University of Thessaly, Larissa, Greece, ${ }^{2}$ Department of Nuclear Medicine, University of Thessaly, Larissa, Greece

Received January 13, 2016

Accepted April 8, 2016

On-line July 15, 2016

\section{Summary}

The aim of the present study was to investigate changes of blood ghrelin, adiponectin and resistin levels in IVF/ICSI-ET cycles. Twenty women were stimulated with recombinant FSH in a GnRH agonist short protocol for IVF/ICSI. Blood samples were taken on cycle day 2 before the commencement of injections, on cycle day 6 and on the days of HCG injection, oocyte pick up (OPU), embryo transfer (ET) as well as 7 and 12 days post-ET. Serum E2 levels increased during the stimulation, peaking on the HCG day and declined thereafter $(p<0.001)$. Serum progesterone levels started to increase on the OPU day, peaking on the ET day $(p<0.001)$ and decreased on days 7 and 12 post-ET. Plasma ghrelin remained unchanged during the whole cycle. Serum adiponectin levels remained stable during the stimulation period until the ET day and decreased on days 7 and 12 post-ET $(p<0.001)$. Serum resistin levels increased until the ET day $(p<0.05)$, remained unchanged on day 7 post-ET and decreased on day 12 post-ET $(p<0.05)$. The present study shows for the first time that ghrelin levels did not change significantly during IVF/ICSI-ET cycles. Resistin levels increased during the stimulation period while adiponectin levels remained stable decreasing during the luteal phase.

\section{Key words}

Ghrelin • Adiponectin • Resistin • IVF

\section{Corresponding author}

K. Dafopoulos, Department of Obstetrics and Gynecology, University of Thessaly, 41110 Larissa, Greece. Fax: 2410626490. E-mail: kdafop@med.uth.gr

\section{Introduction}

Ghrelin is a 28-amino acid hormone mainly produced by the gastric oxyntic glands, and an endogenous ligand for the GH secretagogue receptor type 1a (Angelidis et al. 2012). Ghrelin circulates in blood in acylated and unacylated form. Growth hormone release is strongly stimulated by acylated ghrelin (octanoylation at serine-3), but also the initially considered as biologically inanctive unacylated ghrelin has been shown to exert specific effects on various tissues (Delhanty et al. 2013). Estrogens may have an effect on ghrelin secretion, since in normal pregnant women, plasma ghrelin levels have been found significantly decreased (Makino et al. 2002). However, previous studies in women have shown inconsistent effects of treatment with exogenous estrogen on ghrelin levels in the circulation (Chu et al. 2006, Grinspoon et al. 2004, Kellokoski et al. 2005, Lebenthal et al. 2006). In normally cycling women, we have demonstrated that plasma acylated and unacylated ghrelin levels do not vary significantly throughout the menstrual cycle, despite the physiological fluctuations of ovarian steroids (Dafopoulos et al. 2009).

Adipose tissue is not only storage for triglycerides, but also secretes various molecules, called adipokines. One of them is adiponectin, which besides its insulin-sensitizing, anti-atherosclerotic, and antiinflammatory properties exerts also actions in the female reproductive system (Angelidis et al. 2013). Adiponectin circulates in blood at concentrations that account for 
$0.01 \%$ of total human plasma protein (Arita et al. 1999). Previous studies have shown conflicting results about the effect of estrogens on adiponectin secretion. In our study, we showed that serum adiponectin levels remain unchanged throughout the normal menstrual cycle (Dafopoulos et al. 2009). However, data about the effect of supraphysiological levels of ovarian steroids on blood adiponectin concentrations during superovulation induction are scanty with only one study reporting that following gonadotrophin treatment, serum adiponectin levels decreased, while they increased after HCG administration (Liu et al. 2006).

Resistin is another adipokine and has been suggested as a link between obesity and type 2 diabetes (Steppan et al. 2001). In women, higher resistin levels have been found as compared to men (Silha et al. 2003), suggesting that sex steroids may account for the differential regulation of resistin secretion. We have also investigated serum resistin levels throughout the normal menstrual cycle, and showed that they were unchanged, suggesting that normal variations of estradiol and progesterone do not affect resistin secretion (Dafopoulos et al. 2009).

The objective of the present study was to investigate changes of blood levels of ghrelin, adiponectin and resistin levels during controlled ovarian hyperstimulation with recombinant FSH for multiple follicular developments, when supraphysiological levels of ovarian steroids are attained.

\section{Subject and Methods}

Twenty healthy normally cycling women, aged $31.2 \pm 0.8$ years (26-35 years) with BMI $24.5 \pm 1.9 \mathrm{~kg} / \mathrm{m}^{2}$ $\left(18.3-38.2 \mathrm{~kg} / \mathrm{m}^{2}\right)$, were treated with IVF/ICSI due to tubal or male factor. The women volunteered for the study and gave written informed consent and Institutional Review Board approval of the study was obtained. The inclusion criteria were no drug, alcohol or smoke usage, absence of insulin resistance as assessed by glucose to insulin ratio (G/I) and HOMA-R (insulin resistance was considered as $\mathrm{G} / \mathrm{I}<6$ or HOMA-R $>2.7$ ), no hormonal treatment for the last 3 months including oral contraceptives, and demonstration of ovulatory cycles with ultrasonography and day 21 progesterone measurement ( $>30 \mathrm{nmol} / \mathrm{l})$ before enrollment in the study. All women were stimulated in a short agonist protocol (inl. Arvekap, $0.1 \mathrm{mg}$, Ipsen, Athens, Greece) with recombinant FSH (inj. Puregon, MSD, Athens, Greece).
The HCG injection (5,000 IU, Pregnyl, MSD, Athens, Greece) was given $36 \mathrm{~h}$ before oocyte retrieval when at least three follicles reached $17 \mathrm{~mm}$. Luteal phase support with vaginal progesterone (vag. gel Crinone $8 \%$, Merck, Athens, Greece) was given to all women. From each woman blood samples were taken in the morning, at least two hours after awakening and after overnight fasting, on cycle day 2 (first day of stimulation) before the commencement of FSH and GnRH agonist injections, on cycle day 6 (fifth day of stimulation) and on the days of HCG injection, oocyte pick up (OPU), embryo transfer (ET, two days after the OPU) as well as 7 and 12 days following ET. All blood samples were centrifuged at $1000 \mathrm{~g}$ for $15 \mathrm{~min}$ and serum was stored at $-20{ }^{\circ} \mathrm{C}$ until assayed. Plasma ghrelin and serum adiponectin, FSH, LH, estradiol and progesterone were measured in all blood samples. All hormones were measured in duplicate in each blood sample.

\section{Hormone assays}

Measurement of total ghrelin in plasma was performed using a radioimmuno- assay (RIA) (KIPMR90, BioSource Europe, Nivelles, Belgium). The results are expressed as $\mathrm{pg} / \mathrm{ml}$. Measurement of adiponectin in serum, was performed using a human adiponectin RIA kit (LINCO Research, USA), while serum resistin was measured with an Enzyme Immunoassay (Resistin Elisa KAPME50, BioSource Europe S.A.). The results are expressed as $\mu \mathrm{g} / \mathrm{ml}$ and $\mathrm{ng} / \mathrm{ml}$, respectively. FSH and LH in serum was performed using an immunoradiometric assay (FSH-IRMA and LHsp-IRMA, respectively, BioSource Europe S.A.) and the results are expressed as IU/1. Measurement of estradiol and progesterone in serum was performed using a radioimmunoassay (E2-RIA-CT and PROG-RIA-CT, respectively, BioSource Europe S.A.) and the results are expressed as $\mathrm{pg} / \mathrm{ml}$ and $\mathrm{ng} / \mathrm{ml}$, respectively. The lower limits of detection for ghrelin, adiponectin, resistin, FSH, LH, estradiol and progesterone were $40 \mathrm{pg} / \mathrm{ml}$, $0.001 \mu \mathrm{g} / \mathrm{ml}, 0.006 \mathrm{ng} / \mathrm{ml}, 0.1 \mathrm{IU} / 1,0.2 \mathrm{IU} / 1,2 \mathrm{pg} / \mathrm{ml}$ and $0.05 \mathrm{ng} / \mathrm{ml}$, respectively, while inter- and intra-assay coefficients of variation were 7.5 and 5.0, 9.25 and 6.21, 6.8 and 5, 2.4 and 1.1, 3.4 and 1.4, 6.2 and 4.9, and 6.5 and $3.3 \%$, respectively.

\section{Data analysis}

Hormone values were normally distributed (one sample Kolmogorov-Smirnov test) and statistical analysis was performed by repeated measures one-way analysis of 
variance (ANOVA), followed by Bonferroni post hoc testing. Correlation between variables was performed by Pearson correlation and since the participants ranged in body size from normal weight to obese, all correlations were adjusted for BMI. An $\alpha$ level of 0.05 was used to determine statistical significance. All values are expressed as mean \pm SEM. The statistical software package used was NCSS 2001 (Number Cruncher Statistical Systems, Kaysville, UT, USA).

\section{Results}

Figure 1 shows the dynamics of ovarian steroids and gonadotrophins throughout the stimulation period until the day 12 post-ET. Serum E2 levels increased gradually during the stimulation with $\mathrm{FSH}$, peaking on the day of $\mathrm{HCG}$ injection $(2,973.9 \pm 464 \mathrm{pg} / \mathrm{ml})$ and declined gradually thereafter $(p<0.001)$. Serum progesterone levels were low during the stimulation with FSH but started to increase on the day of OPU, peaking on the day of ET $(47.4 \pm 4.7 \mathrm{ng} / \mathrm{ml}) \quad(\mathrm{p}<0.001)$. Progesterone levels decreased significantly on days 7 and 12 post-ET. Following the HCG injection, serum LH and FSH levels were suppressed during the luteal phase as compared to the stimulation phase, recovering from suppression on day 12 post-ET $(\mathrm{p}<0.001)$.
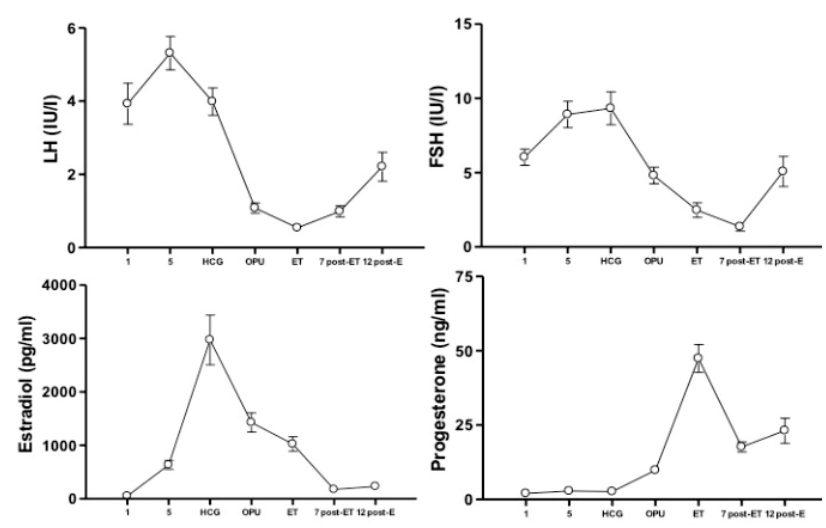

Fig. 1. Serum $\mathrm{LH}, \mathrm{FSH}$, estradiol and progesterone levels (mean \pm SEM) during the ovarian stimulation with recombinant FSH and the luteal phase following HCG administration $\left(1=1^{\text {st }}\right.$ day of stimulation, $5=5^{\text {th }}$ day of stimulation, HCG=day of HCG administration, $\mathrm{OPU}=$ day of oocyte pick up, $\mathrm{ET}=$ day of embryo transfer, 7 post-ET $=7^{\text {th }}$ day after $E T, 12$ post-ET $=12^{\text {th }}$ day after ET).

Plasma total ghrelin was $667.9 \pm 44 \mathrm{pg} / \mathrm{ml}$ before the stimulation with FSH and remained unchanged during the whole study period (Fig. 2). Correlations between hormone values were tested for each day of blood sampling. There were no significant correlations between ghrelin and estradiol or progesterone levels throughout the study period with the exception of day 7 following ET, where a significant negative correlation was found between ghrelin and estradiol levels $(r=-0.687, \mathrm{p}<0.05)$.

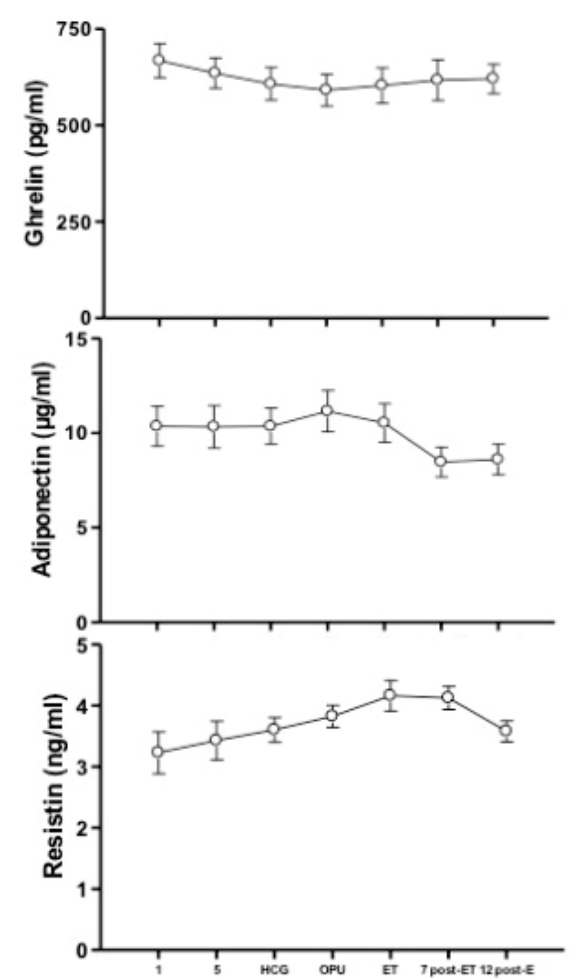

Fig 2. Plasma ghrelin, and serum adiponectin and resistin levels (mean \pm SEM) during the ovarian stimulation with recombinant FSH and the luteal phase following HCG administration ( $1=1^{\text {st }}$ day of stimulation, $5=5^{\text {th }}$ day of stimulation, $\mathrm{HCG}=$ day of HCG administration, OPU=day of oocyte pick up, ET=day of embryo transfer, 7 post-ET $=7^{\text {th }}$ day after $E T, 12$ post-ET $=12^{\text {th }}$ day after ET).

Serum adiponectin levels were $10.3 \pm 1.0 \mu \mathrm{g} / \mathrm{ml}$ before the stimulation with FSH. They remaining stable during the stimulation period until the day of ET and decreased significantly on days 7 and $12(8.6 \pm 0.8 \mu \mathrm{g} / \mathrm{ml})$ post-ET $(\mathrm{p}<0.001)$ (Fig. 2). Adiponectin levels did not correlate with estradiol levels, while a significant negative correlation was found between adiponectin and progesterone levels on the day 7 following ET $(r=-0.566$, $\mathrm{p}<0.05)$.

Serum resistin levels were $3.2 \pm 0.3 \mathrm{ng} / \mathrm{ml}$ before the FSH administration and showed a gradual increase until the day of ET $(4.2 \pm 0.2 \mathrm{ng} / \mathrm{ml}) \quad(\mathrm{p}<0.05)$. They remaining unchanged on day 7 post-ET and decreased significantly on day 12 post-ET $(3.6 \pm 0.2 \mathrm{ng} / \mathrm{ml}, \mathrm{p}<0.05)$ (Fig. 2). 


\section{Discussion}

Our results suggest that increasing blood levels of estradiol to supraphysiological values during the stimulation period have no effect on plasma ghrelin levels. Furthermore, fluctuations of progesterone levels following HCG injection, during the luteal phase, did not affect blood ghrelin levels. This finding is in agreement to our previous study in women during the normal cycle where it was evident that physiological changes of estradiol and progesterone levels during the whole cycle did not modulate the ghrelin secretion in blood (Dafopoulos et al. 2009).

In the present study, it was also found that supraphysiological levels of estradiol during the stimulation period had no effect on serum adiponectin levels. This finding supports previous data in women that were investigated during the whole normal cycle and it was shown that changes of estradiol levels within physiological values had no significant effect on adiponectin levels in the circulation (Asimakopoulos et al. 2009, Dafopoulos et al. 2009, Hall et al. 2009, Kleiblová et al. 2006). In a previous work of our group, we showed that treatment with exogenous estrogens in order to increase blood level of estradiol up to $250 \mathrm{pg} / \mathrm{ml}$, in premenopausal rapidly ( 3 days) and in postmenopausal women in two weeks, had no effect on blood adiponectin levels (Chalvatzas et al. 2009). In the same study, we found that following ovariectomy in premenopausal women, the significant decrease of estradiol levels in circulation did not modify blood adiponectin levels (Chalvatzas et al. 2009).

However, during the luteal phase of the stimulated cycle and in particular, on days 7 and 12 postET, a significant decline in serum adiponectin was found. Although, this reduction was evident after the maximal levels of progesterone in blood were attained, these levels were still very high as compared to those observed during the normal menstrual cycle. The number of our cases is sufficient for repeated measures analysis, but small for correlations on a daily basis. However, it was shown that on every day of blood samplings, adiponectin levels did not correlate with estradiol levels, but on the day 7 following ET, a significant negative correlation was found between adiponectin and progesterone levels. Therefore, progesterone at high supraphysiological levels in circulation may be the candidate factor responsible for the reduction of adiponectin levels, since in the normal cycle the fluctuation of progesterone levels during the luteal phase did not modify adiponectin levels (Dafopoulos et al. 2009). This assumption is further strengthened by a previous study showing that in a mixed population of premenopausal, early pregnant and postmenopausal women the blood levels of total adiponectin, and its high- and medium-molecular weight oligomers were negatively associated with progesterone levels (Leung et al. 2009). In vitro data regarding the role of progesterone on adiponectin secretion from adilose tissue in humans and animals are scanty. In female rats, it was found that progesterone induced a 2-fold decrease of adiponectin mRNA level in inguinal white adipose tissue, an effect that was abolished by RU 486 (Stelmanska et al. 2012).

In contrast to our findings, another previous study in women participating in IVF-ET cycles, showed that serum adiponectin levels decreased from the initiation of stimulation to the day of HCG injection, and then increased on the day of OPU and again on day 7 following ET (Liu et al. 2006). However, in the study by Liu et al. (2006) the population was different including 18 patients with PCOS and 17 patients with endometriosis (out of 52 in total), while in the present study only normally cycling women participated. Liu et al. (2006) used a GnRH antagonist protocol, while we used a short GnRH agonist protocol. In their study, for luteal phase support, intramuscular daily progesterone with 2,000 IU HCG on days 2, 5 and 8 following OPU were given, while in our study daily vaginal progesterone only was administered. The discrepancies in the findings between our study and the study of Liu et al. (2006), although may partly arise from these methodological differences, are difficult to explain and larger studies are needed to unravel this issue.

In the present study, it was also found that serum resistin levels increased significantly during the stimulation period when supraphysiological levels of estradiol were attained. A similar finding was found in a recent study, which showed that in both GnRH agonist and antagonist cycles, stimulated with recombinant $\mathrm{FSH}$, serum resistin levels increased on the days of HCG and ET as compared to the day before the initiation of ovarian stimulation (Siristatidis et al. 2015). These findings are in contrast to previous data showing that in normally cycling women the physiological changes of estradiol in the circulation throughout the menstrual cycle did not affect the serum resistin levels (Dafopoulos et al. 2009). Asimakopoulos et al. (2009) also suggested that resistin levels were similar during the early and late follicular 
phase, although they slightly increased during the luteal phase of the cycle. In the earlier work of our group (Chalvatzas et al. 2009), it was found that acute treatment with exogenous estrogens in premenopausal and the gradually increasing dosing scheme in postmenopausal women did not change circulatory resistin levels. Furthermore, it was shown that ovariectomy in premenopausal women and the subsequent decrease of estradiol levels in circulation had no effect on blood resistin levels (Chalvatzas et al. 2009). Therefore, it is possible that supraphysiological but not physiological levels of estradiol in the blood modify resistin secretion in women. In vitro data in animals are conflicting. In 3T3-L1 adipocytes, it was shown that 17 $\beta$-estradiol up-regulated resistin mRNA expression in a dose- and time-dependent manner (Chen et al. 2006). However, in ovariectomized (OVX) rats and in isolated rat adipocytes in vitro, estradiol benzoate administration reduced resistin mRNA levels in adipocytes of OVX rats, and also estradiol treatment decreased resistin mRNA levels in cultured adipocytes (Huang et al. 2005).

Our results also showed that serum resistin levels remained high when the estradiol levels were falling during the luteal phase. At this time the progesterone levels were high and it is possible that resistin levels remained unchanged due to a stimulatory effect of progesterone. The reduction of serum resistin levels on day 12 post-ET in our cases may be due to the significant reduction of estradiol and progesterone at this time point. This is likely, since a previous in vitro study showed that high progesterone levels in the circulation of rats increased 2-fold the resistin mRNA levels (Stelmanska et al. 2012).

\section{Conclusions}

Estradiol and progesterone are not probably major regulators of ghrelin secretion in women. High levels of progesterone but not estradiol in blood may negatively affect adiponectin secretion, while high levels of both estradiol and progesterone may stimulate resistin secretion in women undergoing superovulation induction for IVF.

\section{Conflict of Interest}

There is no conflict of interest.

\section{Acknowledgements}

No grants or fellow supports.

\section{References}

ANGELIDIS G, DAFOPOULOS K, MESSINI CI, VALOTASSIOU V, GEORGOULIAS P, MESSINIS IE: Ghrelin: new insights into female reproductive system-associated disorders and pregnancy. Reprod Sci 19: 903-910, 2012.

ANGELIDIS G, DAFOPOULOS K, MESSINI CI, VALOTASSIOU V, TSIKOURAS P, VRACHNIS N, PSIMADAS D, GEORGOULIAS P, MESSINIS IE: The emerging roles of adiponectin in female reproductive systemassociated disorders and pregnancy. Reprod Sci 20: 872-881, 2013.

ARITA Y, KIHARA S, OUCHI N, TAKAHASHI M, MAEDA K, MIYAGAWA J, HOTTA K, SHIMOMURA I, NAKAMURA T, MIYAOKA K, KURIYAMA $\mathrm{H}$, NISHIDA $\mathrm{M}$, YAMASHITA $\mathrm{S}$, OKUBO $\mathrm{K}$, MATSUBARA K, ET AL.: Paradoxical decrease of an adipose-specific protein, adiponectin, in obesity. Biochem Biophys Res Commun 257: 79-83, 1999.

ASIMAKOPOULOS B, MILOUSIS A, GIOKA T, KABOUROMITI G, GIANISSLIS G, TROUSSA A, SIMOPOULOU M, KATERGARI S, TRIPSIANIS G, NIKOLETTOS N: Serum pattern of circulating adipokines throughout the physiological menstrual cycle. Endocr J 56: 425-433, 2009.

CHALVATZAS N, DAFOPOULOS K, KOSMAS G, KALLITSARIS A, POURNARAS S, MESSINIS IE: Effect of ovarian hormones on serum adiponectin and resistin concentrations. Fertil Steril 91: 1189-1194, 2009.

CHEN YH, LEE MJ, CHANG HH, HUNG PF, KAO YH: 17 beta-estradiol stimulates resistin gene expression in 3T3-L1 adipocytes via the estrogen receptor, extracellularly regulated kinase, and CCAAT/enhancer binding protein-alpha pathways. Endocrinology 147: 4496-4504, 2006.

CHU MC, COSPER P, NAKHUDA GS, LOBO RA: A comparison of oral and transdermal short-term estrogen therapy in postmenopausal women with metabolic syndrome. Fertil Steril 86: 1669-1675, 2006. 
DAFOPOULOS K, SOURLAS D, KALLITSARIS A, POURNARAS S, MESSINIS IE: Blood ghrelin, resistin, and adiponectin concentrations during the normal menstrual cycle. Fertil Steril 92: 1389-1394, 2009.

DELHANTY PJ, NEGGERS SJ, VAN DER LELY AJ: Des-acyl ghrelin: a metabolically active peptide. Endocr Dev 25 : 112-121, 2013.

GRINSPOON S, MILLER KK, HERZOG DB, GRIECO KA, KLIBANSKI A: Effects of estrogen and recombinant human insulin-like growth factor-I on ghrelin secretion in severe undernutrition. J Clin Endocrinol Metab 89: 3988-3993, 2004.

HALL N, WHITE C, O'SULLIVAN AJ: The relationship between adiponectin, progesterone, and temperature across the menstrual cycle. J Endocrinol Invest 32: 279-283, 2009.

HUANG SW, SEOW KM, HO LT, CHIEN Y, CHUNG DY, CHANG CL, LAI YH, HWANG JL, JUAN CC: Resistin mRNA levels are downregulated by estrogen in vivo and in vitro. FEBS Lett 579: 449-454, 2005.

KELLOKOSKI E, PÖYKKÖ SM, KARJALAINEN AH, UKKOLA O, HEIKKINEN J, KESÄNIEMI YA, HÖRKKÖ S: Estrogen replacement therapy increases plasma ghrelin levels. J Clin Endocrinol Metab 90: 2954-2963, 2005.

KLEIBLOVÁ P, SPRINGER D, HALUZÍK M: The influence of hormonal changes during menstrual cycle on serum adiponectin concentrations in healthy women. Physiol Res 55: 661-666, 2006.

LEBENTHAL Y, GAT-YABLONSKI G, SHTAIF B, PADOA A, PHILLIP M, LAZAR L: Effect of sex hormone administration on circulating ghrelin levels in peripubertal children. J Clin Endocrinol Metab 91: 328-331, 2006.

LEUNG KC, XU A, CRAIG ME, MARTIN A, LAM KS, O'SULLIVAN AJ: Adiponectin isoform distribution in women-relationship to female sex steroids and insulin sensitivity. Metabolism 58: 239-245, 2009.

LIU YH, TSAI EM, CHEN YL, CHEN HS, CHEN YC, WU LC, LEE CH, JONG SB, CHAN TF: Serum adiponectin levels increase after human chorionic gonadotropin treatment during in vitro fertilization. Gynecol Obstet Invest 62: 61-65, 2006.

MAKINO Y, HOSODA H, SHIBATA K, MAKINO I, KOJIMA M, KANGAWA K, KAWARABAYASHI T: Alteration of plasma ghrelin levels associated with the blood pressure in pregnancy. Hypertension 39: 781-784, 2002.

SILHA JV, KRSEK M, SKRHA JV, SUCHARDA P, NYOMBA BL, MURPHY LJ: Plasma resistin, adiponectin and leptin levels in lean and obese subjects: correlations with insulin resistance. Eur J Endocrinol 149: 331-335, 2003.

SIRISTATIDIS C, ASKOXYLAKI M, VAROUNIS C, KASSANOS D, CHRELIAS C: E-selectin, resistin and reactive oxygen species levels in GnRH -agonist and -antagonist protocols in IVF/ICSI: a prospective cohort study. $J$ Assist Reprod Genet 32: 959-967, 2015.

STELMANSKA E, KMIEC Z, SWIERCZYNSKI J: The gender- and fat depot-specific regulation of leptin, resistin and adiponectin genes expression by progesterone in rat. J Steroid Biochem Mol Biol 132: 160-167, 2012.

STEPPAN CM, BAILEY ST, BHAT S, BROWN EJ, BANERJEE RR, WRIGHT CM, PATEL HR, AHIMA RS, LAZAR MA: The hormone resistin links obesity to diabetes. Nature 409: 307-312, 2001. 